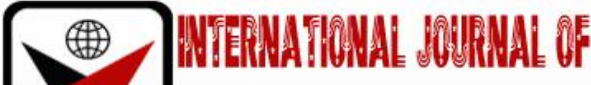

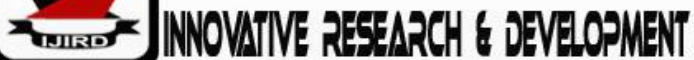

ISSN 2278-0211 (Online)

\section{The Role of Diplomatic Relations, Institutional Response and Conflict Resolution in South Sudan: A Case of Jubek State, South Sudan}

\author{
Dr. Gabriel Alier Riak Achot \\ Associate Professor, Department of Political Science \\ Upper Nile University, South Sudan
}

\begin{abstract}
:
The study investigated the influence of Diplomatic relation on conflict resolution in South Sudan with a particular reference to Juba City in South Sudan. The objectives of the study were to; examine the Role of Diplomatic relation in South Sudan Conflict, assess the indicators of institutional Response in Juba City in South Sudan and to examine the relationship between Diplomatic Relation, institutional response and conflict resolution in South Sudan.

The descriptive design using a case study of Juba City Council and both qualitative and quantitative approaches were used. The study population was 182. Sampling technique was purposive and simple random. The Sample size was 140 respondents from the employees and beneficiaries of Equatorial State in South Sudan and Data was analyzed using descriptive analysis option of SPSS version (20.0).

The major findings of the study were that there is a significant positive correlation between; Diplomatic relations on conflict resolution ( $r=0.632$, $P$-value $<0.01)$, institutional response and conflict resolution $(r=0.512, P$-value $<0.01)$ and the attributes explained $59 \%$ of the variance of Conflict ( $R$ Square $=.518$ ) as the level to which they can predict the level of Conflict resolution in Central Equatorial State of South Sudan. Such that unit change in Diplomatic relations processes will contribute to a change in the possibility of Conflict resolution by (.581) while a one-unit change in and Institutional response will contribute to a change in the Conflict resolution of the Central Equatorial State and other states of South Sudan (343).

The study recommends that the State and Country leaders should develop diplomatic relations with other international communities that aim at empowering people with education values and promoting an electoral process that serves the purpose of national renewal and peace commitment, need to make more use of an integrated application of litigation, alternative dispute resolution mechanisms and traditional justice systems in the management of natural resource conflicts and alternative Dispute Resolution mechanisms such as negotiation, fact finding facilitation and mediation should be adopted since they have the potential to enhance environmental justice since they allow parties to enjoy autonomy over the process and outcome; they are expeditious, cost-effective, flexible and employ non-complex procedures.
\end{abstract}

Keywords: Role of Diplomatic Relation, institutional response, conflict resolution

\section{Introduction}

This chapter presents the introduction, back ground of the study, problem statement, purpose of the study, general and specific objectives, research questions, scope of the study, significance of the study and the conceptual frame work.

Globally, some progress is being made towards achieving the MDGs, but societies affected by armed conflict and criminal armed violence are often off track. These countries are usually in the lower ranks of the Human Development Index (HDI) or are experiencing specific risk factors shaping armed violence onset. For example, in 2012, the UN stated that 22 of the 34 countries farthest from reaching the MDGs are in or emerging from armed conflict (UN's MDG Review Summit, September 2010). This suggests that armed violence is both a cause and consequence of certain forms of underdevelopment. At the time when conflicts have become major impediments to development, the donor community recognizes the need for a special focus in assisting post-conflict recoveries.

Since all the developing countries, including those affected by conflict, attract aid from the same pool of donor funding World Bank, (2011), investigation of the patterns and the determinants that drive aid to post-conflict countries is warranted. The current crisis in South Sudan has worsened humanitarian conditions in a country facing acute needs and 2.5 million people are displaced due to the armed conflict and therefore it embarked to conflict resolution (UNHCR, 2014). Since the outbreak of violence in South Sudan on 15 December 2013, the humanitarian needs have quickly been growing with a total of 195,416 persons have been displaced from the 4 states of South Sudan, namely; Central Equatoria, Jonglei, Unity and Upper Nile, and 75171 of them taking shelter in the UN peace keeping bases in Juba, Bor, Malakal, Bentiu, while 
an estimated 58000 others are displaced in Aweriel County Lakes state (UNMISS, 2014). The current study tries to investigate how Armed Conflict, and Social Capital Institutional Response influence Peace Building in South Sudan.

\subsection{Background to the Study}

Diplomacy refers to the conduct of human affairs by peaceful means, employing techniques of persuasion and negotiation (Barnett and Duvall, 2010). It is known that refers to international diplomacy, the conduct of international relations through the intercession of professional diplomats with regard to issues of peace-making, trade, war, economics, culture, environment and human relations (Berridge, 2005). But it not known that diplomatic relations bring about diplomatic initiatives by outside parties to transform a conflict by enhancing communication between warring parties and providing information about the conflict that can help generate movement toward negotiated outcomes (Little, 2007). The functions of diplomatic relations are also particularly closely related to evolving events and issues such as international crises, human and natural disasters or outbreaks of violence, which shift the diplomatic spotlight on to previously remote geographic areas or issues (Guzzini, 2009). Diplomatic relation is measured by the following attributes; economic relations, political relations, cultural relations and environmental relations (Claude, 2012).

Institutional Response define as an argues that the role of institutions needs to be recognized in resilience building because, while the technical aspects of mitigation measures are important, their acceptance by the institutions should not be underestimated. In Uganda for example operating outside the disaster management policy and established institutions during disaster relief may be disastrous to a particular organization or individual Ekotu, (2012). Fatemeh, (2011) argues for a synergy whereby civic engagement should serve to strengthen state institutions and where effective state institutions create an environment in which civic engagement is more likely to thrive. Institutional response has the following attributes, Efficiency, Impact, Effectiveness and Relevance (Brooks, 2011).

Conflict resolution is a process in which one party perceives that its interests are being opposed or negatively affected by another party. It promotes human rights, to improve good governance and rule of law. It is based on the concept that conflicts are a normal part of human interaction and are rarely completely resolved or eliminated, but they can be managed by such measures as negotiation, mediation, conciliation, and arbitration (Gleick, 2012). Conflict resolution encompasses all the activities involved in raising, discussing, and resolving both inter-user and contentcentered conflicts (Abadi, 2011). Conflict resolution supports the longer-term development of societal systems and institutions that enhance good governance, rule of law, security, economic sustainability, and social well-being, which helps prevent future conflicts (Leung, 2009). It also enhances learning and group outcomes, organization setting, properly managed conflict reduces direct and indirect suffering and deaths among the people involve (Mwagiru, 2011). Conflict resolution is measured by attributes like; need for management, judicial mechanisms, negotiation, mediation and arbitration (Hossein Abadi, 2011).

\subsection{Statement of the Problem}

Globally conflicts have led to loss of more than 1.8 billion lives and $75 \%$ of total deaths and suffering comes from Sub-Saharan Africa Countries. Conflict hinder the achievement of the conflict management and more generally, social, economic, political and human development (UNSG, 2009). Conflict/ or Violence affects all societies, cities and population groups at all income levels. According to recent estimates, at least 740,000 people die annually directly or indirectly due to armed violence (UNDP, 2014).

In Nigeria, conflicts have resulted in the deaths of thousands of civilians, over 2.1 million people were internally displaced in northern Nigeria; 92\% of them lived in host communities, while the remainder lived in camps (Amnesty International, 2016). In Chad,130,000 people have been displaced by the war. In South Sudan, 740,000 people are displaced due to the armed conflict (UNDP, 2014).

Despite several attempts to breach or resolve conflict between South and North of the then Sudan, in Naivasha, Kenya, which gave birth to Independent South Sudan in 9. July.2011 and; the ongoing effort or process to bring to an end the recent internal Armed Conflict in Addis Ababa, Ethiopia, yet fragility remains unabated. Such journeys have prompted question as to what is direly /or barely needed to achieve permanent peace resolution which will intern to peace Build in South Sudan (CPA, Jan, 2005).

Prospectively, whenever an Armed Conflict erupts there is no peace. Conflict resolution can only be achieved once there is permanent peace (when atmosphere is conducive), which can also lead to achievement of permanent peace. South Sudan had been engaged in bloody conflicts between Sudan and its own self. To quell those disturbances into peaceful settlements, the government of South Sudan has tried many ways, but all efforts were frustrated to a continuation of the conflict between the warring parties (UNDP, 2014).

Delivering assistance to those in need is a top priority for relief agencies, where security allows. Hygiene and sanitation have emerged as problems in areas where the displaced are gathering, and U.N. officials indicate that food, water, healthcare, and shelter are urgently needed a fact which shows that armed conflict, institutional response, social capital, and peace building have been put at stake. The study investigates the effect of diplomatic relations and institutional response on conflict resolution South Sudan.

\subsection{Purpose of the Study}

The study investigated the role of Diplomatic relations and Institutional response on Conflict resolution with a particular reference to Juba County in South Sudan. 


\subsection{Specific Objectives}

- To examine the impact of Diplomatic relations on Conflict resolution

- To assess the relationship between Institutional response and Conflict resolution

- To examine the influence of Diplomatic relations and Institutional response on Conflict resolution

\subsection{Research Questions}

- What is the relationship between Diplomatic relations on Conflict resolution?

- What are the indicators of Institutional response and Conflict resolution?

- What is the influence of Diplomatic relations and Institutional response on Conflict resolution?

\subsection{Scope of the Study}

\subsubsection{Content Scope}

The study assessed the relationship between Diplomatic relations, Institutional response and Conflict resolution in South Sudan

\subsubsection{Geographical Scope}

The study was carried out in the headquarters of Central Equatorial State in South Sudan because it the main business center of the Country, targeting their employees and residents of the state. Central Equatorial State is one of South Sudan's 29 states. It falls along river Nile (White Nile). It is at the extreme South of the country, barely $190 \mathrm{~km}$ from Ugandan border to the south. It is also a country's commercial hub hosting many economic migrants, investors, pettytraders from other regions of the country as well as East Africa and Asia. This significant has attracted geographical focus of the study to Juba

\subsubsection{Time Scope}

The study reviewed records from 2009-2014. And it was carried out from May 2016 to August 2016.

\subsection{Significance of the Study}

\subsubsection{Academic}

The issues raised in this study are likely to lead to the involvement of various researchers in generating more knowledge from various perspectives of conflict resolution in Juba county and South Sudan as a whole. The findings of this study can form a basis for further research to those interested to research on diplomatic relations and its impacts on conflict resolution. On the other hand, this study will also benefit this individual researcher in finalizing his study programme.

\subsubsection{Industry Significance}

The study can be used by other different international organizations to discover the strategies that can be used to manage conflict. Managements and other bodies can come up with new strategies which will help them advice the stakeholders on how to handle conflict.

\subsubsection{Policy Makers}

The study may assist government and other policy making bodies to develop policies and guidelines which will provide a conducive operating environment for reconciliation and management of the conflict which will lead to sustainable peace in South Sudan. The study can also benefit the policy makers at both national and institutional levels through policy formulation and change of polices in regard to hoe diplomatic relations and resource sharing affect conflict management.

\subsubsection{Development Partners}

The study can assist development partners especially international agents like INGOs and foreign countries in knowing the factors behind the conflict management in some countries such that they can be used in war torn/ conflict areas. 


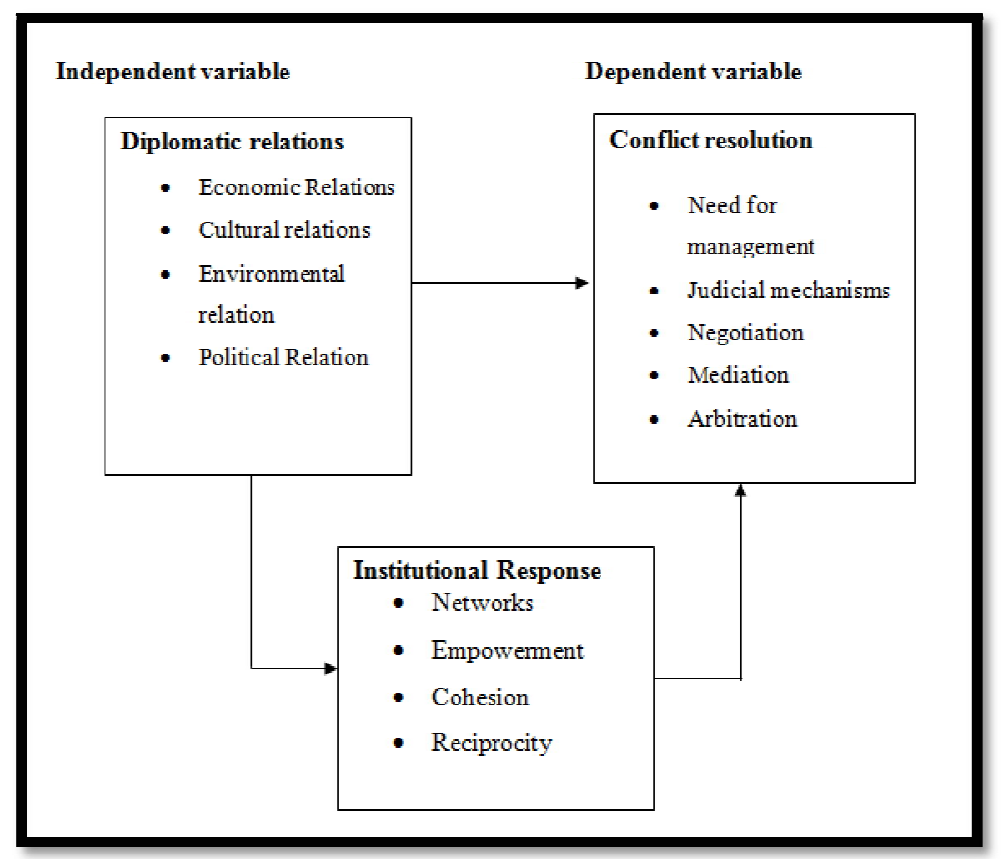

Figure 1: Conceptual Framework

\subsection{Description of the Conceptual Framework}

Diplomatic relations will be measured based on the International diplomatic relations model by (Guzzini, 2009) which measured it using attributes like; economic relations, political relations, cultural relations and environmental relations; Institutional response is measured based on the resource model by Somerville, (2012) with attributes like; Social Networks, Cohesion, Reciprocity, and access to resources. And Conflict resolution is measured based on the Rahim's meta-model, 2002with attributes like; need for management, judicial mechanisms, negotiation, mediation and arbitration (Hossein Abadi, 2011).

\section{Literature Review}

\subsection{Introduction}

This chapter reviews the existing literature put forward by different scholars and personalities on Diplomatic relations, Institutional response and Conflict resolution as well as the relationship among the three variables based on the objectives of the study.

\subsection{The Impact of Diplomatic Relations on Conflict Resolution}

\subsubsection{Diplomatic Relations}

Diplomacy refers to the conduct of human affairs by peaceful means, employing techniques of persuasion and negotiation (Barnett and Duvall, 2010). It usually refers to international diplomacy, the conduct of international relations through the intercession of professional diplomats with regard to issues of peace-making, trade, war, economics, culture, environment and human relations (Berridge, 2005). Diplomacy is typically carried out by government officials, who use bargaining, negotiation, and other peaceful means to negotiate treaties, trade policies, and other international agreements, including agreements to prevent, limit, manage, or settle conflicts (Claude, 2012).

Diplomatic relations are often thought of as being concerned with peaceful activity, although it may occur within war or armed conflict or be used in the orchestration of particular acts of violence, such as seeking over-flight clearance for an air strike (Lake and Powell, (eds) 2013). International treaties are usually negotiated by diplomats prior to endorsement by national politicians (Lake and Powell, (eds) 2013). In an informal or social sense, diplomacy is the employment of tact to gain strategic advantage or to find mutually acceptable solutions to a common challenge, one set of tools being the phrasing of statements in a non-confrontational or polite manner (Barnett and Duvall, 2010). Diplomatic relation is measured by the following pillars;

\subsubsection{Peace diplomacy}

Underlying Country's peace and security diplomacy is the recognition of peace and stability as necessary preconditions for development and prosperity. A country should have a conviction that its own stability and economic wellbeing are dependent on the stability of the sub-region, Africa and the rest of the world (Berridge, 2005). The objectives of this pillar are to: Promote the resolution of conflicts by peaceful means; Collaborate with other African countries to strengthen the conflict prevention, management and resolution capacity of regional institutions, including the EAC, IGAD, COMESA and AU with the aim of promoting sustainable peace and development. And to support peace efforts by the African Union and the United Nations through contributing troops and providing leadership in peacekeeping missions within the continent and globally (Claude, 2012). 


\subsubsection{Economic Diplomacy}

Countries' quest for a peaceful and stable environment is linked to its socio-economic development and prosperity, and that of the region (Choi \& Choi, 2008). A robust economic engagement is necessary to secure the Country's regional and overall economic objectives. The objectives of this pillar are to: Increase capital flows to the Country; Support export promotion and investment by enterprises within the region and beyond; Promote the country as a favorite destination for foreign direct investment, tourism, and conferencing; Expand access to traditional markets and explore new destinations for the Country's exports; Enhance technological advancement by exploring new sources of affordable and appropriate technology (Claude, 2012). And Strengthen regional economic communities and organizations to serve as competitive spring boards to emerging and global markets (Cohen \& Westbrook, Eds. 2012).

\subsubsection{Diaspora Diplomacy}

The Government should recognize the huge and untapped potential of her citizens abroad which can contribute to the country's national development agenda (Claude, 2012). The Diaspora pillar aims to harness the diverse skills, knowledge, expertise and resources of the citizens living abroad, and facilitating their integration into the national development agenda (Guzzini, 2009). This informs the Diaspora Pillar which seeks to harness the contribution of citizens living abroad through the implementation of the National Diaspora policy (David and Powell, (eds) 2013).

\subsubsection{Environmental Diplomacy}

The Environmental Policy underscores that environment and natural resources are valuable national assets upon which the country's sustainable development is anchored. Countries recognize their enormous stake in the sustainable management of its own natural resources, those of the region and the world. Countries are encouraged to champion the strengthening of UNEP and UN HABITAT in prioritizing the global sustainable development agenda; Promote compliance with the relevant national, regional and international environmental legislation, regulations, standards, and other appropriate operational procedures and guidelines; Promote the integration of environmental management into national and regional economic activities, including agriculture and tourism to minimize negative impact on the environment and promote research as a mechanism to encourage innovation and reduce adverse environmental impacts.

\subsubsection{Cultural Diplomacy}

It is through cultural activities that a nation's idea of itself is best represented. A country's cultural diplomacy should aim at increasing awareness of her cultural richness and to generate interests in the country's cultural heritage. There should be respect and recognition of cultural diversity and heritage; Promotion of cultural exchanges and partnerships and promotion of global intercultural dialogue.

\subsubsection{Conflict Resolution}

Conflict resolution is a general term that describes efforts to prevent, limit, contain, or resolve conflicts, especially violent ones, while building up the capacities of all parties involved to undertake peace-building (Muigua, 2011). It is based on the concept that conflicts are a normal part of human interaction and are rarely completely resolved or eliminated, but they can be managed by such measures as negotiation, mediation, conciliation, and arbitration (Gleick, 2012). Conflict resolution also supports the longer-term development of societal systems and institutions that enhance good governance, rule of law, security, economic sustainability, and social well-being, which helps prevent future conflicts (Leung, 2009). A closely related term is peacemaking, although peacemaking tends to focus on halting ongoing conflicts and reaching partial agreements or broader negotiated settlements (Stiftung, 2014).

Conflict resolution includes the various on-wiki spaces for discussing conflicts, as well as the formal and informal roles played by community members (e.g. mediators, admins, Arbitration Committees) (International Alert et al. 2011). The aim of conflict resolution is to enhance learning and group outcomes, including effectiveness or performance in organizational setting (Samuel, 2012). Properly managed conflict can improve group outcomes (Green, 2012). Conflict resolution patterns are often according to Desivilya et al. (2005) related to a dual concern model divided into concern for self and concern for others (Leung, 2009). Further different conflict management approaches are based on these two motives, some focusing more on concern for self or concern for others (David, 2012).

Conflict resolution in the high stress environment of the operating room (Somerville, 2012). Scott, (2011) concludes that conflict is inevitable, especially in highly stressed environments. Therefore, he believes, professional organizations and employers have a responsibility to recognize that people approach conflict differently and should provide opportunities for multidisciplinary audiences to learn and develop conflict management skills and thereby change their interpersonal environments (Segal \& Melinda, 2011). Therefore, it is important to identify effective conflict management strategies for conflict resolution (Victor, 2012). The methods of performing conflict resolution in the traditional are as follows: mediation, adjudication, reconciliation, arbitration and negotiation. It also includes employing extra-judicial devices and usage of legal maxims to persuade or convince the disputants about the implication or otherwise of their behavior.

\subsubsection{Need for Management}

The need to achieve sustainable development calls for sustainable management of natural resources in the region through engaging all the relevant stakeholders (Kameri Mbote et al., 2011). It has been persuasively argued that in environmental conflicts where there is high level emotional intensity, several of the early casualties in verbal and nonverbal skirmishes are tolerance and communication with people stopping to listen to those espousing contrary views and 
begin associating exclusively with like-minded supporters (Fiske, 2011). It is imperative to look at each of the approaches with an aim to identify their efficacy in managing natural resource conflicts and disputes (Hossein Abadi, 2011).

\subsubsection{Judicial Mechanisms}

With the objective of settling disputes in a more justifiable manner, national governments and the constitutions of most nations establish institutions; judiciary organs of the government. It is the natural mandate of courts of law to entertain disputes (Fiske, 2011). Courts in Somalia and even elsewhere in the world have encountered a number of problems related to access to justice. These include high court fees, geographical location, complexity of rules and procedure and the use of legalese (Hossein Abadi, 2011). The court's role is also 'dependent on the limitations of civil procedure, and on the litigious courses taken by the parties themselves' (Kameri Mbote et al., 2011). Courts thus play an important and indispensable role in achieving sustainable development which means conflicts must be dealt with effectively (Abadi, 2011).

\subsubsection{Negotiation}

Negotiation is a process that involves parties meeting to identify and discuss the issues at hand so as to arrive at a mutually acceptable solution without the help of a third party (Hamilton, 2014). It may be argued that negotiation is by far the most efficient conflict management mechanism in terms of management of time, costs and preservation of relationships and has been seen as the preferred route in most disputes (Hamilton, 2014). Negotiation can be interestbased, rights-based or power-based and each can result in different outcomes (Abadi, 2011). However, the most common form of negotiation depends upon successfully taking and the giving up a sequence of positions (Amendola, 2011). Negotiation can be used in facilitating the effective management of natural resources-based conflicts (UNESCO-IHP, 2014).

\subsubsection{Mediation}

Mediation is defined as the intervention in a standard negotiation or conflict of an acceptable third party who has limited or no authoritative decision-making power but who assists the involved parties in voluntarily reaching a mutually acceptable settlement of issues in dispute (Muigua, 2011). Mediation has been defined as a continuation of the negotiation process by other means where instead of having a two-way negotiation, it now becomes a three-way process: the mediator in essence mediating the negotiations between the parties (Moore, 2009). It is also a mechanism worth exploring as it has been successfully used to achieve the right of access to justice for parties (Mwagiru, 2011).

\subsubsection{Arbitration}

Arbitration is a dispute settlement mechanism. Arbitration arises where a third party neutral (known as an arbitrator) is appointed by the parties or an appointing authority to determine the dispute and give a final and binding award (Chau, (2007). Its advantages are that parties can agree on an arbitrator to determine the matter; the arbitrator has expertise in the area of dispute; any person can represent a party in the dispute; flexibility; cost-effective; confidential; speedy and the result is binding (UNCITRAL, 2008).

There is an influence of diplomatic relations on conflict resolution because the implementation of these pillars provides a guiding framework for diplomatic engagements. This will further guide the country as it pursues its vision of becoming peaceful, prosperous and globally competitive while promoting sustainable development (Welsh, 2014). Effective diplomatic relations, support and effective coordination in the conflict management process stimulates parties favoring the peace agreement to meet their commitments and thereby diminishes the possibility of hostility (Muigua, 2011). In most cases it is important for the strong diplomatic relations as it leads to commitment with international peacekeepers, whose presence can "deter defections from the peace treaty (Doyle and Sambanis, 2006). Shokouh Abadi, (2011) adds that diplomatic initiatives as attempts by outside parties can transform a conflict by enhancing communication between warring parties and providing information about the conflict that can help generate movement toward negotiated outcomes. In addition, the outside parties can tie information to explicit carrots or sticks by linking diplomacy to possible economic or military interventions.

\subsection{The Relationship between Institutional Response and Conflict Resolution}

\subsubsection{Institutional Response}

Institutional Response define as an argues that the role of institutions needs to be recognized in resilience building because, while the technical aspects of mitigation measures are important, their acceptance by the institutions should not be underestimated. In Uganda for example operating outside the disaster management policy and established institutions during disaster relief may be disastrous to a particular organization or individual Ekotu, (2012). Fatemeh, (2011) argues for a synergy whereby civic engagement should serve to strengthen state institutions and where effective state institutions create an environment in which civic engagement is more likely to thrive. Institutional response has the following attributes, Efficiency, Impact, Effectiveness and Relevance (Brooks, 2011).

\subsubsection{Efficiency}

Bishnu, (2012) defines the efficiency of a production unit in terms of a comparison between observed and optimal values of its output and input. The comparison can take the form of the ratio of observed to maximum potential output obtainable from the given input, or the ratio of minimum potential to observed input required producing the given output. In these two comparisons the optimum is defined in terms of production possibilities, and efficiency is technical. 


\subsubsection{Impact}

Impact considers the measurement of conditions of victims and structures before interventions in relation to those after interventions. Intervention impact is considered positive if the conditions of victims and structures have been restored to a level similar to those before a disaster or even better and considered negative otherwise (Allahdadi, 2011).

\subsubsection{Effectiveness}

Effectiveness focuses on the quality of services and size of the victims reached out to during a response intervention. The ability of an institution to provide basic needs to victims and to help them realize that they can get back to their previous state or even better is a prime determinant on how effective an intervention operation is rated (Allahdadi, 2011).

\subsubsection{Relevance}

Locally organized responsive action to disasters could be very powerful to limit damage and losses, and that they are crucial to complement higher level activities in emergencies. Local institutions and organizations are key actors with comparative strengths for response programmes and they derive their strength from proximity, responsiveness to social pressures and adaptation (FAO, 2009).

\subsubsection{Cohesions}

Social cohesions focus more specifically on social bonds and their dual potential to include or exclude members of community. Cohesion can be demonstrated through community events or through activities that increase solidarity, strengthen togetherness; improve communication, for coordinated group activities. DFID, (2012) observes that by improving the efficiency of economic relations, social capital can help increase people's incomes and saving and so build on financial capital and livelihoods.

There is a relationship between Institutional response, Social capital and conflict resolution in that by improving the efficiency of economic relations, can help increase people's incomes and saving and so build on financial capital and livelihoods. Communities with institutions are strong and democratic. Social networks facilitate innovation, the development of knowledge and sharing of that knowledge (DFID, 2012). Nigel, (2013) argues that in remote and marginalized communities where the rural economy is weak, opportunities are few and education resources are scarce, effective and efficient rural education, which incorporates practical and technical skills appropriate to the rural context, is important in the sustainable livelihoods of rural communities. Both Institutional responses empower people, organizations and society to systematically stimulate and develop their capabilities over time to achieve social and economic goal, observed (DFID, 2012).

\subsection{The Influence of Diplomatic Relations and Institutional Response on Conflict Resolution}

According to the UNESCO-IHP, (2014) and Warner, (2014), attempts through diplomatic relations can alter the course of a conflict through providing material, intelligence and financial support to change the structure of the relationship among combatants, or alternatively, providing information through mediation and other diplomatic initiatives to change the information that they hold about their adversary. The approaches reached at through diplomatic relation can have conflict management goals, although mediation has a much more direct link to a goal of containing violence and making peace (Ury \& Goldberg, 2014). Both Institutional responses empower peoples' organizations and society to systematically stimulate and develop their capabilities over time become democratic for conflict management and achieve social and economic goal, observed DFID (2012).

\section{Methodology}

\subsection{Introduction}

This chapter presents the research methodology that was applied in conducting the study. This involved the research design, target population, sampling design and sample size, data collection procedures and instrument, determination of reliability and validity as well as data analysis techniques.

\subsection{Research Design}

The research design was a case study and descriptive. In addition, the study adopted a triangulation of both quantitative and qualitative approaches for data collection and analysis. In this case, the quantitative approach allowed the researcher to solicit information expressed in numerical format while the qualitative approach complemented the quantitative approach by soliciting more detailed information expressed in textual format (Mugenda \& Mugenda, 1999).

\subsection{Study Population}

The research was carried out in Central Equatorial State. The population comprised of 193 people from the county. The researcher clustered this to 8 Administrative staff, 35 Operational staff and 150 citizens of Equatorial State (Table 1) 


\begin{tabular}{|c|c|}
\hline Target Group & Population \\
\hline Administrative staff & 8 \\
\hline Operational staff & 35 \\
\hline Citizens & 150 \\
\hline Total & 193 \\
\hline
\end{tabular}

Table 1: Population Size

Source: Primary Data

\subsection{Sampling Procedure}

The researcher used both probability and non-probability sampling techniques so as to be exhaustive in the research findings. Random sampling used as a probability technique to obtain a good representative sample of the area population of the residents. Purposive sampling technique was used as a non-probability technique for the leaders of the state only but as key informants.

\subsection{Sample Size and Selection Strategy}

The sample size was calculated using the Krejcie and Morgan Table (1970) for determining the sample, as this gave a practical ratio based on the State's population size. According to Krejcie and Morgan Table, approximately 193 respondents will be used as a sample size of the entire population (182). The researcher clustered this population into one of 8 administrators, 30 operational staff and 108 residents of Central Equatorial State as explained in Table 2 below.

\begin{tabular}{|c|c|c|}
\hline Target Group & Population & Sample \\
\hline Administrative staff & 8 & 8 \\
\hline Operational staff & 35 & 30 \\
\hline Citizens & 150 & 108 \\
\hline Total & 193 & 164 \\
\hline
\end{tabular}

Table 2: Sample Size Distribution

Source: Primary Data

\subsection{Data Sources}

\subsubsection{Primary Data}

The study used primary data that was collected using questionnaire and observation these instruments are appropriate as it helped the researcher to collect information that was directly observable as it was about feelings, motivations; attitudes, accomplishments as well as experiences of individuals (Sutrisna, 2009).

\subsubsection{Secondary Data}

Desk research method used on secondary data. Secondary data refer to data collected by someone other than the researcher conducting the current study (Saunders et al., 2009). Text books, annual reports, journals and magazines were some of the documents reviewed.

\subsection{Research Methods}

\subsubsection{Survey}

A survey was used to collect data from Heads of Sections, supervisors and support staff. The choice of a questionnaire is on the basis that respondents can read and write and enables responding to the study questions without influence on the presence of the respondent. Kabanza (2001) affirms that questionnaires cover big area over a short period of time. It also allowed respondents to respond boldly and frankly to questions. The questionnaire enabled collection of vast amounts of data in a short time and was less expensive (Amin, 2005).

\subsection{Data Collection Instruments}

\subsubsection{Closed Questionnaire}

A structured questionnaire was used to obtain information from respondents (Amin, 2005). The questionnaire is an efficient data collection method which has advantages of high complete responses within a short period. Use of questionnaires allowed the respondents ample time to reflect on answers to avoid hasty responses and thus enhance the validity (accuracy) of the responses (Mugenda \& Mugenda, 2003). The questionnaire method also helped to reduce on the cost and time implications, besides enabling greater responses.

\subsection{Validity and Reliability of Research Tools}

The validity of the questionnaires established using the content validity test. Using the ratings, the content validity indices were computed. The Cronbach Alpha method of internal consistency was used to compute the reliability of the measures of the variables of the study using various questionnaire items administered to respondents (Kothari, 1990). When the Cronbach Alpha coefficients for the study variables are above 0.60 , the scales used to measure the study 
variables was consistent and therefore reliable and meeting acceptance standards for the research. This is also similar with the sighting of Sekyawa (2009).

\begin{tabular}{|c|c|c|c|}
\hline Variable & Anchor & $\begin{array}{c}\text { Cronbach Alpha } \\
\text { Coefficient }\end{array}$ & $\begin{array}{c}\text { CVR(Content } \\
\text { Validity Ratio) }\end{array}$ \\
\hline Diplomatic relations & 5 point & 0.8250 & 0.8050 \\
\hline Institutional response & 5 point & 0.7825 & 0.7150 \\
\hline Conflict resolution & 5 point & 0.7525 & 0.7350 \\
\hline
\end{tabular}

Table 3: Validity and Reliability of the Instrument Variable

Source: Primary Data

Since all Content Validity indices for all experts and Alpha coefficients were above 0.8, then the items/questions selected for the study were relevant to the study variables

\subsection{Measurement of Variables}

- Diplomatic relations were measured using a five-point Likert type scale (1- strongly disagree, 2-Disagree, 3-Not sure, 4- Agree and 5-Strongly agree) based on the based on the International diplomatic relations model by (Guzzini, 2009) which measured it using attributes like; economic relations, political relations, cultural relations and environmental relations.

- Institutional response was measured using a five-point Likert type scale (1- strongly disagree, 2-Disagree, 3-Not sure, 4- Agree and 5-Strongly agree) based on the on the resource model by Somerville, (2012) with attributes like; Social Networks, Cohesion, Reciprocity, and access to resources.

- Conflict resolution was measured using a five-point Likert type scale (1- strongly disagree, 2-Disagree, 3-Not sure, 4- Agree and 5-Strongly agree) based on the Rahim's meta-model, 2002with attributes like; need for management, judicial mechanisms, negotiation, mediation and arbitration (Hossein Abadi, 2011).

\subsection{Ethical Considerations}

Maximum effort was ensured to observe ethical principles to ensure that bias is eliminated and maximize meaning of information provided. Respect for all intellectual property where all the secondary data was properly documented and referenced. The respect for respondents was ensured regarding information provided, and non-discrimination to allow willing and equal participation. In addition, no client was coerced to give the information, but was convinced to give the feedback at will, in this study. The researcher recognized the rights of individuals to privacy, personal data protection and freedom of movement. Masculinity was put in consideration especially in cultures where it is associated with self-esteem. Finally, all the data collected was destroyed after capturing and analysis.

\subsection{Data Process and Analysis}

Statistical package for the social sciences (SPSS) was used to aid to process and summarize the information got from the questionnaires. The data was sorted, coded and fed into the SPSS data analyst to generate various results. The data was analyzed for descriptive statistics, that is, frequencies, percentages, mean and standard deviation. Using Pearson correlation coefficient of determination, inferential statistics like correlations was used to illustrate the existence of the relationship between variables (if any), while the regression analysis was used to explain how the independent variables affect the dependent variable.

\subsection{Anticipated Limitations and Problems Encountered}

The researcher encountered the following limitations

- Sensitivity of information; some of the staff were reluctant to respond to some of the questions since they deal with government information. The researcher assured them of maximum confidentiality so they can provide all the required information.

- Busy schedules; some key informant respondents had busy schedules and lack time to participate in the study. The researcher made appointments with the respondents in order to meet at appropriate times for the interviews.

- Unwillingness to fill the questionnaires; some respondents were unwilling to share information about their leaders, supervisors, workmates and the service system. The researcher however endeavored to emphasize that it is a purely academic research and confidentiality was upheld.

- Interpretation of the questions may affect the meaning as some respondents can get difficulty in interpreting the questions correctly since English is not used as the national language. However, the researcher tried to interpret the questions for them where necessary.

\section{Analysis and Interpretation of Study Findings}

\subsection{Introduction}

This chapter discusses the response rate, Bio data, Pearson correlation, factor loadings, Standard and Deviation 


\subsection{Respondents' Bio Data}

The response rate was $85 \%$ (140 respondents).

\subsubsection{Gender of Respondents}

Table 4below presents the gender distribution of the respondents.

\begin{tabular}{|c|c|c|}
\hline Gender & Frequency & Percent \\
\hline Male & 88 & 62.9 \\
\hline Female & 52 & 37.1 \\
\hline Total & 140 & 100.0 \\
\hline
\end{tabular}

Table 4: Gender by Respondent Distribution Source: Primary Data Computed

The result in Table 4indicates that at $62.9 \%$ were males and $37.1 \%$ were females.

4.2.2 Age Group of the Respondents

Table 5 below presents the age of the respondents

\begin{tabular}{|c|c|c|}
\hline Age Group & Frequency & Percent \\
\hline $41-50$ years & 58 & 41.4 \\
\hline $31-40$ years & 41 & 29.3 \\
\hline $21-30$ years & 28 & 27.1 \\
\hline $50+$ years & 13 & 9.3 \\
\hline Total & 140 & 100.0 \\
\hline
\end{tabular}

Table 5: Age Group of the Respondents Source: Primary Data Computed

The results in Table 5 indicate that $41.4 \%$ of respondents were between the age ranges of 41 - 50 years. In addition, those within the age bracket of $31-40$ were $29.3 \%$. Those who were between the age's range of 21 - 30 years were followed with a statistical representation of 27.1\%. 9.3\% were between the age range of 50 and above.

\subsubsection{Marital Status of the Respondents}

The table below 6 presents marital status of respondents

\begin{tabular}{|c|c|c|}
\hline Marital Status & Frequency & Percent \\
\hline Married & 87 & 62.1 \\
\hline Single & 33 & 23.6 \\
\hline Separated & 12 & 8.6 \\
\hline Divorced & 8 & 5.7 \\
\hline Total & 140 & 100.0 \\
\hline
\end{tabular}

Table 6: Marital Status of the Respondents Source: Primary Data Computed

The result in Table 6 indicates that $62.1 \%$ of respondents were married, $23.6 \%$ were single, $8.6 \%$ had divorced and $5.7 \%$ were separated.

\subsubsection{Respondents' Number of Dependents}

The table below 7 presents the number of dependents for the respondents.

\begin{tabular}{|c|c|c|}
\hline Number of Dependents & Frequency & Percent \\
\hline 1 to 3 & 56 & 40.0 \\
\hline 4 to 5 & 48 & 34.3 \\
\hline Above 5 & 25 & 17.9 \\
\hline None & 11 & 7.8 \\
\hline Total & 140 & 100.0 \\
\hline
\end{tabular}

Table 7: Respondents' Number of Dependents Source: Primary Data Computed

The result in Table 7 above indicates that $40 \%$ of the respondents were with dependents ranging from 1 to 3 . In addition, $34.3 \%$ had 4 to 5 dependents, $17.9 \%$ had above 5 dependents and $7.8 \%$ had no dependents.

\subsubsection{Respondents' Level of Education}

The table below 8 presents the educational levels of the respondents. 


\begin{tabular}{|c|c|c|}
\hline Level of Education & Frequency & Percent \\
\hline Tertiary & 45 & 32.1 \\
\hline Diploma & 32 & 22.8 \\
\hline Certificate & 23 & 16.4 \\
\hline Primary & 18 & 12.8 \\
\hline Never studied & 17 & 12.2 \\
\hline Masters & 5 & 3.6 \\
\hline Total & 140 & 100.0 \\
\hline
\end{tabular}

Table 8: Respondents' Level of Education

Source: Primary Data Computed

The result in Table 8 above indicates that 32.1\% of the respondents were holding a degree as their level of education, $22.8 \%$ had attained diplomas, $16.4 \%$ were holding certificates as their level of education, $12.8 \%$ studied up to primary level of education and $12.2 \%$ had never studied while the remaining $3.6 \%$ had Master level of education.

\subsubsection{Respondents' Working Experience}

The table below 9 presents the number of years the respondents have been working/ using the company's products

\begin{tabular}{|c|c|c|}
\hline Working Experience & Frequency & Percent \\
\hline 6 and Above & 57 & 40.7 \\
\hline $4-6$ years & 38 & 27.1 \\
\hline $4-4$ years & 22 & 15.7 \\
\hline $1-2$ years & 16 & 11.4 \\
\hline Less than 1 year & 5 & 3.6 \\
\hline Total & 140 & 100.0 \\
\hline
\end{tabular}

Table 9: Respondents' Working Experience

Source: Primary Data Computed

The results in Table 9 above show that $40.7 \%$ of the respondents had a working experience of 6 years and above. In addition, $27.1 \%$ had a working experience of 5 to 6 years, $15.7 \%$ had 3 to 4 years working experience, followed by respondents with a working experience of 1 to 2 years $11.4 \%$ and $3.6 \%$ as the least with an experience of less than 1 year.

\subsection{Relationship between Studies}

Spearman correlation coefficient was used to determine the degree of relationship between the study variables as shown in the Table 10below.

\begin{tabular}{|c|c|c|c|}
\hline & 1 & 2 & 3 \\
\hline Diplomatic relations (1) & 1.000 & & \\
\hline Institutional response (2) & $.432^{* *}$ & 1.000 & \\
\hline Conflict resolution (3) & $.632^{* *}$ & $.512^{* *}$ & 1.000 \\
\hline
\end{tabular}

Table 10: Pearson's Zero Order Correlation Matrix

** Correlation Is Significant at the .01 Level (2-Tailed)

Source: Primary Data

\subsubsection{The Impact of Diplomatic Relations on Conflict Resolution}

The results in Table 10above indicate a positive impact of Diplomatic relations on conflict resolution $(\mathrm{r}=0.632$, $\mathrm{P}$-value $<0.01$ ) which implies that any change in diplomatic relations influence the conflict resolution processes in a state like Central Equatorial State and South Sudan as a whole.

\subsubsection{The Relationship between Institutional Response and Conflict Resolution}

The results in Table 10above indicate a positive relationship between institutional response and conflict resolution $(\mathrm{r}=0.512$, P-value $<0.01$ ) which implies that institutional responses influence the conflict resolution processes in a state like Central Equatorial State and South Sudan as a whole.

\subsubsection{The Influence of Diplomatic Relations and Institutional Response on Conflict Resolution}

Regression analysis was used to examine the level at which diplomatic relations and institutional response determine the level of conflict resolution in Central Equatorial State of South Sudan.

Table 11 below shows the regression model for diplomatic relations and institutional response and conflict resolution 


\begin{tabular}{|c|c|c|c|c|c|}
\hline \multirow{2}{*}{ Model } & \multicolumn{2}{|c|}{$\begin{array}{c}\text { Un-Standardized } \\
\text { Coefficients }\end{array}$} & $\begin{array}{c}\text { Standardized } \\
\text { Coefficients }\end{array}$ & \multicolumn{2}{|c|}{} \\
\cline { 2 - 6 } & B & Std. Error & Beta & T & Sig \\
\hline Constant & -0.175 & 1.734 & & .041 & .509 \\
\hline Diplomatic relations & .482 & .452 & .581 & 1.023 & .425 \\
\hline Institutional response & .323 & .615 & .343 & .451 & .311 \\
\hline
\end{tabular}

Table 11: The Regression Model for Diplomatic Relations and Institutional Response and Conflict Resolution $R=0.634 R$-Square $=0.588$, Adjusted $R$-Square $=0.301, F=4.332$, Sig $=1.011$

Source: Primary Data Computed

Results in Table 11 above show $(\mathrm{R}=0.634)$ a combination of Diplomatic relations and Institutional response in assessing the level to which they can predict the level of Conflict resolution in Central Equatorial State of South Sudan. These variables explained 59\% of the variance of Conflict resolution (R Square =.518). The most influential predictor of Conflict was Diplomatic relations $(\beta=.581$, Sig. 425$)$. Institutional response is less likely to influence Conflict resolution since it portrays low significance $(\beta=.343$, Sig. 311$)$ in the model.

A unit change in Diplomatic relations processes will contribute to a change in the possibility of Conflict resolution by (.581) while a one-unit change in and Institutional response will contribute to a change in the Conflict resolution of the Central Equatorial State and other states of South Sudan (343).

\subsection{The Factor Loadings of Diplomatic Relations, Institutional Response and Conflict Resolution}

\subsubsection{Factor Analysis of Diplomatic Relations}

\begin{tabular}{|c|c|c|c|c|}
\hline Variables & 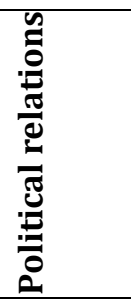 & 总 & 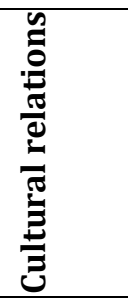 & 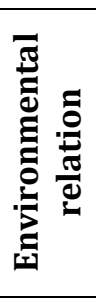 \\
\hline $\begin{array}{l}\text { There are mediations, international forums for conflict } \\
\text { management }\end{array}$ & .930 & & & \\
\hline $\begin{array}{l}\text { There were requests for diplomatic intervention during the } \\
\text { conflict management processes }\end{array}$ & .918 & & & \\
\hline $\begin{array}{l}\text { The Country tried to recall the ambassadors and explicit offers to } \\
\text { mediate in the conflict management process }\end{array}$ & .901 & & & \\
\hline $\begin{array}{l}\text { There has been lowering of barriers to such trade and it leads to } \\
\text { trade wars and tariff }\end{array}$ & & .893 & & \\
\hline $\begin{array}{l}\text { Economic relations affect global alliances, globalization and the } \\
\text { economic health of nations }\end{array}$ & & .864 & & \\
\hline $\begin{array}{l}\text { There are recommends to develop, encourage, and maintain these } \\
\text { relations among diverse nations and cultures }\end{array}$ & & .841 & & \\
\hline There are interactions, both direct and indirect & & & .832 & \\
\hline $\begin{array}{l}\text { Cultural relations create pathways that can be leveraged to } \\
\text { prevent or resolve conflict }\end{array}$ & & & .815 & \\
\hline $\begin{array}{l}\text { The available cultural relations have created opportunities for } \\
\text { engagement with the goal of preventing and resolving conflicts }\end{array}$ & & & .807 & \\
\hline $\begin{array}{l}\text { There is management of the environmental relations between } \\
\text { states and between states and other actors }\end{array}$ & & & & .812 \\
\hline $\begin{array}{l}\text { Diplomacy is concerned with advising, shaping and implementing } \\
\text { environmental foreign policy }\end{array}$ & & & & .804 \\
\hline $\begin{array}{l}\text { States coordinate and secure particular or wider interests of the } \\
\text { environmental policies }\end{array}$ & & & & .773 \\
\hline Eigen Value & 1.289 & .183 & 2.454 & $\begin{array}{l}2.389 \\
4\end{array}$ \\
\hline Variance \% & 83.788 & 11.654 & 2.454 & 1.271 \\
\hline Cumulative & 83.788 & 95.442 & 98.729 & 100 \\
\hline
\end{tabular}

Table 12: Factor Analysis of Diplomatic Relations

Source: Primary Data Computed 
The results in Table 12 show the factor analysis results of Diplomatic relations variables, four factors were extracted, component one (Political relations) explains 83.8\%, followed by Economic Relations 11.7\%, the third (Cultural relations) 3.3\% and the last (Environmental relation) 1.3\% of the variance of Diplomatic relations.

The factor analysis results of Diplomatic relations under Political relations attribute were explained that; there are mediations, international forums for conflict management $93 \%$, there were requests for diplomatic intervention during the conflict management processes $92 \%$ and that the Country tried to recall the ambassadors and explicit offers to mediate in the conflict management process $91 \%$.

Under Economic Relations attribute, they were explained that; there has been lowering of barriers to such trade and it leads to trade wars and tariff $89 \%$, Economic relations affect global alliances, globalization and the economic health of nations $86 \%$ and that there are recommends to develop, encourage, and maintain these relations among diverse nations and cultures $84 \%$.

With the Cultural relations attribute, the results were explained that; there are interactions, both direct and indirect among two or more cultures 83\%, Cultural relations create pathways that can be leveraged to prevent or resolve conflict $82 \%$ and that the available cultural relations have created opportunities for engagement with the goal of preventing and resolving conflicts $81 \%$.

Lastly under Environmental relation attribute, they were explained that; there is management of the environmental relations between states and between states and other actors 81\%, Diplomacy is concerned with advising, shaping and implementing environmental foreign policy $80 \%$ and that the States coordinate and secure particular or wider interests of the environmental policies $77 \%$.

\subsubsection{Factor Analysis of Institutional Response}

\begin{tabular}{|c|c|c|c|c|}
\hline Variables & 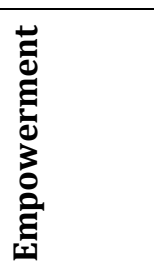 & 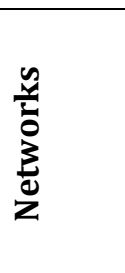 & $\begin{array}{l}\mathscr{3} \\
\frac{0}{0} \\
\frac{\pi}{0}\end{array}$ & 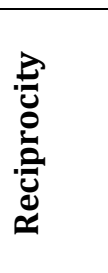 \\
\hline $\begin{array}{l}\text { There is concern for Children skipping school as it could be } \\
\text { important for sustainable development }\end{array}$ & .912 & & & \\
\hline There is equal access to housing in the Country & .884 & & & \\
\hline $\begin{array}{l}\text { There is Concern for Disrespect for adults and other } \\
\text { marginalized persons }\end{array}$ & .854 & & & \\
\hline There is education for all & & .835 & & \\
\hline $\begin{array}{l}\text { The institutions and government try to prevent crime in the } \\
\text { community }\end{array}$ & & .811 & & \\
\hline Counseling services are offered to victims of war & & .804 & & \\
\hline People in the community talk freely with others & & & .795 & \\
\hline I feel comfortable with people with different means $\backslash$ and class & & & .774 & \\
\hline $\begin{array}{l}\text { Social cohesions focus more specifically on social bonds } \\
\text { through Solidarity. }\end{array}$ & & & .753 & \\
\hline $\begin{array}{l}\text { There is provision of resources by an individuals and } \\
\text { repayment of resource of equivalent value }\end{array}$ & & & & .743 \\
\hline $\begin{array}{l}\text { High levels of social capital give rise to high level of reciprocal } \\
\text { relationship }\end{array}$ & & & & .722 \\
\hline There is more with cooperative and well-functioning societies & & & & .705 \\
\hline Eigen Value & 2.220 & 2.45 & 0.695 & 0.479 \\
\hline Variance \% & 71.393 & 15.136 & 8.902 & 4.569 \\
\hline Cumulative & 71.393 & 86.529 & 95.431 & 100 \\
\hline
\end{tabular}

Table 13: Factor Analysis of Institutional Response Source: Primary Data

The results in Table 13 above show the factor analysis results of Institutional Response variables, four factors were extracted, component one (Empowerment) explains 71.4\%, followed by Networks shows 15.1\%, the third (Cohesions) explained it with 8.9\% and the lass was Reciprocity with 4.6\% of the variance of Institutional Response.

The factor analysis results of Institutional Response under Empowerment attribute, they were explained that; there is concern for Children skipping school as it could be important for sustainable development 91\%, there is equal access to housing in the Country $88 \%$ and that there is Concern for Disrespect for adults and other marginalized persons $85 \%$.

With Networks attribute, the results were explained that; there is education for all 84\%, the institutions and government try to prevent crime in the community $81 \%$ and that Counseling services are offered to victims of war $81 \%$. While with Cohesion attribute, they were explained that; People in the community talk freely with others (Freedom of Speech) $80 \%$, I feel comfortable with people with different means $\backslash$ and class $77 \%$ and that Social cohesions focus more specifically on social bonds through Solidarity $75 \%$. 
Lastly under Reciprocity attribute; there is provision of resources by an individuals and repayment of resource of equivalent value 74\%, High levels of social capital gives rise to high level of reciprocal relationship $72 \%$ and that There is more with cooperative and well-functioning societies $71 \%$.

4.4.3. Factor Analysis of Conflict Resolution

\begin{tabular}{|c|c|c|c|c|}
\hline Variables & 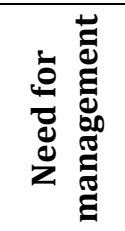 & 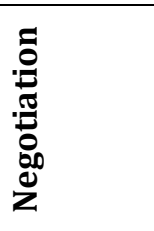 & 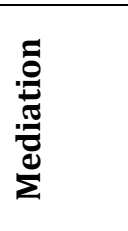 & 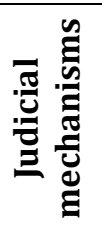 \\
\hline $\begin{array}{c}\text { All the relevant stakeholders are engaged in the management of } \\
\text { the natural resources }\end{array}$ & .914 & & & \\
\hline $\begin{array}{l}\text { Leaders try to emotions manage the emotions of the citizens } \\
\text { effectively to avert full blown conflicts }\end{array}$ & .893 & & & \\
\hline $\begin{array}{l}\text { People can meaningfully benefit from the exploitation of the } \\
\text { natural resources in an atmosphere of managed conflicts }\end{array}$ & .860 & & & \\
\hline $\begin{array}{l}\text { Negotiation has been used in facilitating the effective } \\
\text { management of conflicts }\end{array}$ & & .853 & & \\
\hline $\begin{array}{l}\text { Negotiation has been involving parties meeting to identify and } \\
\text { discuss the issues at hand }\end{array}$ & & .841 & & \\
\hline $\begin{array}{l}\text { Leaders use efficient conflict management mechanisms in } \\
\text { terms of management of time, costs }\end{array}$ & & .828 & & \\
\hline $\begin{array}{l}\text { It is the natural mandate of courts of law to entertain disputes } \\
\text { in Juba County }\end{array}$ & & & .749 & \\
\hline $\begin{array}{c}\text { Courts in South Sudan have encountered a number of problems } \\
\text { related to access to justice }\end{array}$ & & & .728 & \\
\hline The citizens have problems with paying court fees & & & .716 & \\
\hline $\begin{array}{l}\text { There has been a continuation of the negotiation process by } \\
\text { other means where instead of having a two-way negotiation }\end{array}$ & & & & .638 \\
\hline $\begin{array}{l}\text { Leaders use efficient conflict management mechanisms with } \\
\text { mediators }\end{array}$ & & & & .620 \\
\hline $\begin{array}{l}\text { Mediators have been successfully used to achieve the right of } \\
\text { access to justice for parties. }\end{array}$ & & & & .601 \\
\hline Eigen Value & 2.776 & .782 & .403 & .039 \\
\hline Variance $\%$ & 66.398 & 19.549 & 10.069 & 3.984 \\
\hline Cumulative & 66.398 & 85.947 & 96.016 & 100 \\
\hline
\end{tabular}

The results in Table 14 shows the factor analysis results of Conflict resolution variables, four factors were extracted, component one (Need for management) explains 66.4\%, followed by Negotiation 19.55\%, the third (Mediation) $10.07 \%$ and the last (Judicial mechanisms) $3.9 \%$ of the variance of Conflict resolution.

The factor analysis results of Conflict resolution under Need for management attribute were explained that; all the relevant stakeholders are engaged in the management of the natural resources $91 \%$, Leaders try to emotions manage the emotions of the citizens effectively to avert full blown conflicts $89 \%$ and that Institutions have efficient teams for response $94 \%$.

Under Negotiation attribute, they were explained that; Negotiation has been used in facilitating the effective management of conflicts $85 \%$, Negotiation has been involving parties meeting to identify and discuss the issues at hand $84 \%$ and that Leaders use efficient conflict management mechanisms in terms of management of time, costs83\%.

With Mediation attribute, the results were explained that; it is the natural mandate of courts of law to entertain disputes in Juba County 75\%, Courts in South Sudan have encountered a number of problems related to access to justice73\% and that the citizens have problems with paying court fees $73 \%$.

Lastly under Judicial mechanisms attribute, the results were explained that; there has been a continuation of the negotiation process by other means where instead of having a two-way negotiation64\%, Leaders use efficient conflict management mechanisms with mediators62\% and that Mediators have been successfully used to achieve the right of access to justice for parties $60 \%$.

\section{Discussion of the Findings}

\subsection{Introduction}

This chapter presents interpretation of the study findings. 


\subsection{Bio Data}

\subsubsection{Gender of the Respondents}

The results indicated that at $62.9 \%$ were males and $37.1 \%$ were females. The results are attributes are attributed to the ongoing conflicts in the Country which have displaced a lot women. It also implied that most of the employees at the state were males. However, obtaining information from both male and female is an indicator that the information contained in this report is gender sensitive hence the report data being genuine.

\subsubsection{Age Group of the Respondents}

The results indicated that $41.4 \%$ of respondents were between the age ranges of $41-50$ years. In addition, those within the age bracket of $31-40$ were $29.3 \%$. Those who were between the age's ranges of $21-30$ years were followed with a statistical representation of $27.1 \% .9 .3 \%$ were between the age range of 50 and above. This implied that most of the employees and the citizens that participated in the study were between the age range of 41 - 50 years, an indicator that the state employs mature and energetic people who can effectively carry out all possible policies of diplomacy to avoid political instabilities as well as approaches towards better institutional responses for improved conflict resolution. Therefore, presentation of data obtained from mature respondents of above 41 years means that data contained in this study is good and reasonable.

\subsubsection{Marital Status of the Respondents}

The result indicated that $62.1 \%$ of respondents were married, $23.6 \%$ were single, $8.6 \%$ had divorced and $5.7 \%$ had separated from their partners. This implies that most of the employees engaged in implementing policies possible policies of diplomacy to avoid political instabilities as well as approaches towards better institutional responses for improved conflict resolution and many of the stakeholders in the state were married which is a sign of responsibility.

\subsection{4 .Number of Dependents for the Respondents}

The results indicated that $40 \%$ of the respondents were with dependents ranging from 1 to 3 . In addition, $34.3 \%$ had 4 to 5 dependents, $17.9 \%$ had above 5 dependents and $7.8 \%$ had no dependents. This implied that most of the employees and citizens of the state were responsible people since most of them had dependents to cater for.

\subsubsection{Education Levels of the Respondents}

Results indicated that $32.1 \%$ of the respondents were holding a degree as their level of education, $22.8 \%$ had attained diplomas, $16.4 \%$ were holding certificates as their level of education, $12.8 \%$ studied up to primary level of education and $12.2 \%$ had never studied while the remaining 3.6\% had Master level of education. This implied that the workers had acquired some skills to work in the state since some of the workers had acquired a reasonable level of education. However, the leaders in the County needed to lay strategies to improve education of the beneficiaries. The results also indicated that the information got during the research can be depended on as majority of the respondents were educated with capability of researching and making independent decisions.

\subsubsection{Number of Years the Respondents Have Been Working with the Juba County}

The results showed that $40.7 \%$ of the respondents had a working experience of 6 years and above. In addition, $27.1 \%$ had a working experience of 5 to 6 years, $15.7 \%$ had 3 to 4 years working experience, followed by respondents with a working experience of 1 to 2 years $11.4 \%$ and $3.6 \%$ as the least with an experience of less than 1 year. Most of the respondents who participated in this study had stayed in the state for 6 and above years, an indication that data obtained was from people who were mature with working experience in the state and that information got from them was not biased.

\subsection{The Relationship between the Variables}

\subsubsection{The Impact of Diplomatic Relations on Conflict Resolution}

The results indicated a positive impact of Diplomatic relations on conflict resolution $(r=0.632, \mathrm{P}$-value $<0.01)$ which implied that any change in diplomatic relations influence the conflict resolution processes in a state like Central Equatorial State and South Sudan as a whole.

The results are supported by Welsh, (2014) who said that the implementation of these pillars provides a guiding framework for diplomatic engagements. This will further guide the country as it pursues its vision of becoming peaceful, prosperous and globally competitive while promoting sustainable development. Muigua, (2011) adds that effective diplomatic relations, support and effective coordination in the conflict management process stimulates parties favoring the peace agreement to meet their commitments and thereby diminishes the possibility of hostility.

Shokouh Abadi, (2011) concludes that diplomatic initiatives as attempts by outside parties can transform a conflict by enhancing communication between warring parties and providing information about the conflict that can help generate movement toward negotiated outcomes. 


\subsubsection{The Relationship between Institutional Response and Conflict Resolution}

The results indicate a positive relationship between institutional response and conflict resolution $(\mathrm{r}=0.512$, Pvalue $<0.01$ ) which implied that institutional responses influence the conflict resolution processes in a state like Central Equatorial State and South Sudan as a whole.

The results are in line with Nigel, (2013) who argues that in remote and marginalized communities where the rural economy is weak, opportunities are few and education resources are scarce, effective and efficient rural education, which incorporates practical and technical skills appropriate to the rural context, is important in the sustainable livelihoods of rural communities. Both Institutional responses empower people, organizations and society to systematically stimulate and develop their capabilities over time to achieve social and economic goal, observed DFID (2012).

\subsubsection{The Influence of Diplomatic Relations and Institutional Response On Conflict Resolution}

Results explained 59\% of the variance of Conflict (R Square =.518) as the level to which they can predict the level of Conflict resolution in Central Equatorial State of South Sudan. Such that unit change in Diplomatic relations processes will contribute to a change in the possibility of Conflict resolution by (.581) while a one-unit change in and Institutional response will contribute to a change in the Conflict resolution of the Central Equatorial State and other states of South Sudan (343).

The results are in line with UNESCO-IHP, (2014) and Warner, (2014), who attempt through diplomatic relations can alter the course of a conflict through providing material, intelligence and financial support to change the structure of the relationship among combatants, or alternatively, providing information through mediation and other diplomatic initiatives to change the information that they hold about their adversary. Ury \& Goldberg, (2014) adds that the approaches reached at through diplomatic relation can have conflict management goals, although mediation has a much more direct link to a goal of containing violence and making peace.

\section{Conclusions and Recommendations}

\subsection{Introduction}

This chapter highlights the major conclusion and recommendations of the study. The findings are outlined in direct response to the specific objectives. Recommendations have been provided to incorporate diplomatic relations and institutional response on conflict resolution in Juba County and South Sudan as a whole and further research.

\subsection{Conclusions}

The study established that in general terms variables including public diplomatic relations and institutional response play a big role in improving on conflict resolution in any state and the country at large. This trend shows that there is actually a need for improvement in diplomatic relations and institutional response policiesas the best way to improve conflict resolution.

The challenge however, is that the current diplomatic relations and natural resource institutional response policies have not been given a priority yet it greatly determines conflict resolution. in any Country.

If environmental justice and democracy are to be achieved, then there is need to adopt an integrated approach to both conflict resolution and dispute settlement mechanisms in order to promote peace, coexistence, justice for all and participation by all the involved parties. Therefore, Counties in any Country should set and implement clear and effective diplomatic relations, improve institutional response policies towards policies which will ultimately lead to better conflict resolution in the South Sudan and Equatorial State in particular.

\subsection{Recommendations}

Basing on the study findings and the conclusions, the researcher derived the following recommendations:

- The State and Country leaders should develop diplomatic relations with other international communities that aim at empowering people with education values and promoting an electoral process that serves the purpose of national renewal and peace commitment. And to promote an electoral process that serves the purposes of national renewal and peace the commitment of the international community is imperative as questions of how to address peace-building and electoral assistance have received extensive attention.

- The study recommends that all organizations and stakeholders invest heavily in educating their staff and sensitizing their beneficiaries about the need for peace building and where need be, set up education programs for their staff in a bid to build their institutions.

- There is a need to make more use of an integrated application of litigation, alternative dispute resolution mechanisms and traditional justice systems in the management of natural resource conflicts. Litigation is desirable in that it is able to secure compliance by bringing unwilling parties to the process and also giving a binding outcome that is enforceable without further agreement.

- The study recommends that lobbying be done for more organizations to join in and engage in the peace building process in order to fully curb the issue of armed conflicts and also improve the rate at which peace building is being attained. 
- Alternative Dispute Resolution mechanisms such as negotiation, fact finding facilitation and mediation should be adopted since they have the potential to enhance environmental justice since they allow parties to enjoy autonomy over the process and outcome; they are expeditious, cost-effective, and flexible and employ noncomplex procedures. They greatly enhance the principle of public participation in natural resources management. They result in mutually satisfying outcomes which essentially resolves the conflict thus achieving lasting peace among the previously conflicting parties.

\subsection{Areas for Further Future Research}

This study has identified the need to investigate and analyse the role of civil society organizations in restoring family links and reconciliation in rural area, this as will help establish how civil society organizations can help promote peace building in South Sudan.

\section{Dedication}

I dedicate this report to my family in particular my wife Rebecca Amour Manyang, my Son Riak Alier Riak who supported me endlessly without question. Thank you for being there for me, showering me with your love and tolerance for the long hours away from home as I pursued my studies.

\section{Acknowledgement}

First, I would like to express my sincere gratitude and appreciation to our almighty God for enabling and guiding me through my academic life. I am grateful to Honourable Biar Deng Biar, Judge Jok Moch Awan, Prof: James Ajuong Arou, Gen, Johnson Juma Okot, Gen. Malual Majok, Dor Dut Dor, David Ngong kucha, Peter Agot Alier Agot, Gai Deng Biar, Mayom Makuei Biar Mawut Makuei Ajak Jok, Judge James Ayuen Alier and they Entirely Staffs of Cavendish University Uganda for the academic enrichment they have offered me through their IRD program.

My vote of thanks goes to my supervisor Dr Edward Kymbadde who patiently guided me throughout the entire work. Special thanks also go to the employees and citizens of Juba County in South Sudan for sparing their time for interviews and to fill in questionnaires; without them, this research would not have been done. I once again thank all, including the categories not mentioned above, who encouraged and contributed to the completion of this work.

\section{References}

i. Abosede Babatunde, 'Environmental Conflict and the Politics of Oil in the Oil-Bearing Areas of Nigeria's Niger Delta', University of Peace, The Peace and Conflict Review, Volume 5, Issue 1, 2010.

ii. Andrew F. Amendola, (2011). 'Combating Adversarialism in Negotiation: An Evolution towards More Therapeutic Approaches’ Nujs Law Review 4 Nujs L. Rev. pp. 347-370.

iii. Antonia Engel and Benedikt Korf, 'Negotiation and mediation techniques for natural resource management' Food and Agriculture Organization of The United Nations, Rome, 2014, p. 22

iv. Badler, Howard (2008), September). Conflict management in the workplace. Training news. Retrieved March 27, 2012

v. Barnett, Michael and Duvall, Raymond (2010) 'Power in International Politics', International Organization, 59 (1):39-75.

vi. Berridge, G. R. (2005). Diplomacy: Theory and Practice, 3rd edn. Basingstoke: Palgrave.

vii. Claude, Inis L. (2012) Power and International Relations. New York: Random House.

viii. Christina Leb (2012) The right to water in a trans-boundary context: emergence of seminal trends, Water International, 37:6, pp. 640-653 at p. 640, DOI: 10.1080/02508060.2012.710950.

ix. Christopher Moore, (2009). The Mediation Process: Practical Strategies for Resolving Conflict, 3rd, (San Francisco: Jossey-Bass Publishers. Summary written by Tanya Glaser, Conflict Research Consortium.

x. Cloke, K., (2010). "The Culture of Mediation: Settlement vs. Resolution", The Conflict Resolution Information Source, Version IV, December 2005

xi. Convention on Biological Diversity, 2011-2020, United Nations Decade on Biodiversity: Living in Harmony with Nature.

xii. Cohen, R. \& Westbrook, R. (Eds.) (2012). Amarna Diplomacy: The Beginnings of International Relations. Baltimore, Md.: Johns Hopkins University Press.

xiii. Conflict Management Techniques, (2012). Conflict Resolution model, (2012). Retrieved April 20, 2012.

xiv. Convention on Biological Diversity (CBD), (2008), Article 2. Water Secure World - Global Water Partnership', Available at http://www.gwp.org/The-Challenge/What-is-IWRM/ Accessed on 15th August, 2014.

xv. Cooper, A., Hocking, B. \& Maley, W. (Eds.), (2008). Global Governance and Diplomacy: Worlds Apart? Houndmills: Palgrave.

xvi. Guzzini, Stefano (2009). Realism in International Relations and International Political Economy. London: Routledge.

xvii. Emmett P. Fiske, (2011). 'Reconceptualising Environmental Conflict Resolution: The Developmental Facilitation Approach', p. 1.

xviii. Farooq Khan, (2009). Alternative Dispute Resolution, A paper presented Chartered Institute of ArbitratorsKenya Branch Advanced Arbitration Course held on 8-9th March 2007, at Nairobi.

xix. Gleick, P.H., (2012). 'Water and Conflict: Fresh Water Resources and International Security', International Security, Vol. 18, No. 1 pp. 79-112 
xx. Hamilton, G., (2014) 'Rapporteur Report: Alternative Dispute Resolution (ADR) —Definitions, Types and Feasibility' International Investment and ADR.

xxi. Heinrich Boll Stiftung, (2014) 'Roadmap to prosperity through sustainable Natural resources management in the East and Horn of Africa', Essay of the East and Horn of African Delegates.

xxii. International Alert et al. (2011). Conflict-Sensitive Approaches to Development, Humanitarian Assistance and Peace building: Tools for Peace and Conflict Impact Assessment: A Resource Pack. Edited by AfricaPeace Forum (APFO), Center for Conflict Resolution (CECORE), Consortium of Humanitarian Agencies (CHA), Forum on Early Warning and Early Response (FEWER), International Alert and Safer world.

xxiii. K. W. Chau, (2007). Insight into resolving construction disputes by mediation/ Arbitration in Hong Kong, Journal of Professional Issues in Engineering Education and Practice, ASCE / APRIL 2007, pp 143-147 at P. 143.

xxiv. World Bank (2013). World Bank Development Report 2001. Washington, D.C. The World Bank.

xxv. McGraw-Hill

xxvi. World Health Report, Performance of developing countries' health financial systems for quality health delivery, (2010).

xxvii. World Health Organisation, improving national health accounting systems for better health care, 25 June (2012), Accessed on 4th January (2012).

\section{Questionnaire}

\section{Appendix}

\section{Citizens' Questionnaire}

Dear Sir/ Madam

I am a student at Cavendish University a Bachelor's Degree in International Relations and Diplomacy. As one of the requirements for the award of the above degree, I am required to carry out a research project. The research is to investigate the impact of Diplomatic relations and Institutional response on Conflict resolution with particular reference to Central Equatorial State in South Sudan. These questions are intended to facilitate this study. You have been randomly selected as a beneficiary of the above organization and you are kindly requested to spare some time and voluntarily respond to the following questions. All your responses will be treated confidentially.

Your input is highly appreciated.

\section{Section A: Bio data}

1. Gender

Male

Female

2. Age Group

$21-30$ yrs.

$31-40$ yrs.

$41-50$ yrs.

$50+$ yrs

3. Marital status

Single Married

Divorced

Others

4. Number of dependents

None $\square \quad \begin{array}{lllll}\square & \square-3 & \square-6 \quad \square \quad \text { Above } 6\end{array}$

5. Level of education

Secondary school 1 Certificate $3 \square$ Diploma 4 Degree 5 Masters 6

6. Number of years spent staying in the state
1 year
1-2 Yrs
2-4 Yrs
$4-6$ Yrs
over 6 Yrs

Section B: Diplomatic Relations

Please check your feelings on Diplomatic relations by following the rating below and tick the appropriate choice: 5 - Strongly Agree (SA) 4 - Agree (A) 3 - Undecided (UD) 2 -Disagree (D) 1 - Strongly Disagree (SD) 


\begin{tabular}{|c|c|c|c|c|c|c|}
\hline & $\begin{array}{l}\text { Please indicate the rate at which you rank Diplomatic relations } \\
\text { Strategies in this company. Tick the scale }\end{array}$ & & & & & \\
\hline & & 1 & 2 & 3 & 4 & 5 \\
\hline & Economic Relations & & & & & \\
\hline 1 & There is increase in international trade & & & & & \\
\hline 2 & $\begin{array}{l}\text { There has been lowering of barriers to such trade and it leads to trade } \\
\text { wars and tariff }\end{array}$ & & & & & \\
\hline 3 & Economic relations results in improved international relations & & & & & \\
\hline 4 & $\begin{array}{l}\text { Economic relations affect global alliances, globalization and the economic } \\
\text { health of nations }\end{array}$ & & & & & \\
\hline 5 & $\begin{array}{l}\text { There are recommends to develop, encourage, and maintain these } \\
\text { relations among diverse nations and cultures }\end{array}$ & & & & & \\
\hline & Cultural Relations & & & & & \\
\hline 6 & $\begin{array}{l}\text { There are interactions, both direct and indirect among two or more } \\
\text { cultures }\end{array}$ & & & & & \\
\hline 7 & $\begin{array}{l}\text { Cultural relations create pathways that can be leveraged to prevent or } \\
\text { resolve conflict }\end{array}$ & & & & & \\
\hline 8 & $\begin{array}{l}\text { The available cultural relations have created opportunities for engagement } \\
\text { with the goal of preventing and resolving conflicts }\end{array}$ & & & & & \\
\hline 9 & $\begin{array}{l}\text { The challenge of differences in language, understanding, perceptions and } \\
\text { practices between the military and the cultural communities have been } \\
\text { overcome }\end{array}$ & & & & & \\
\hline 10 & $\begin{array}{l}\text { Culture is important in struggles that are increasingly global, especially in } \\
\text { terms of how to engage the effectiveness of adversarial engagement }\end{array}$ & & & & & \\
\hline & Environmental Relation & & & & & \\
\hline 11 & $\begin{array}{l}\text { There is management of the environmental relations between states and } \\
\text { between states and other actors }\end{array}$ & & & & & \\
\hline 12 & $\begin{array}{l}\text { Diplomacy is concerned with advising, shaping and implementing } \\
\text { environmental foreign policy }\end{array}$ & & & & & \\
\hline 13 & $\begin{array}{l}\text { States coordinate and secure particular or wider interests of the } \\
\text { environmental policies }\end{array}$ & & & & & \\
\hline 14 & There are good environmental relations in the County & & & & & \\
\hline 15 & Environmental relations help in conflict management & & & & & \\
\hline & Political Relation & & & & & \\
\hline 16 & There are all forms of diplomatic interventions & & & & & \\
\hline 17 & There are mediations, international forums for conflict management & & & & & \\
\hline 18 & South Sudan has got good political relations with other countries & & & & & \\
\hline 19 & $\begin{array}{l}\text { There were requests for diplomatic intervention during the conflict } \\
\text { management processes }\end{array}$ & & & & & \\
\hline 20 & $\begin{array}{l}\text { The Country tried to recall the ambassadors and explicit offers to mediate } \\
\text { in the conflict management process }\end{array}$ & & & & & \\
\hline
\end{tabular}

Table 15: Diplomatic Relations

Section C: Institutional Response

\begin{tabular}{|c|c|c|c|c|c|c|}
\hline & $\begin{array}{l}\text { To what extent do you agree with the following statements? } \\
\text { Tick the scale }\end{array}$ & 1 & 2 & 3 & 4 & 5 \\
\hline & Empowerment & & & & & \\
\hline 1 & $\begin{array}{l}\text { There is concern for Children skipping school as it could be } \\
\text { important for sustainable development }\end{array}$ & & & & & \\
\hline 2 & There is equal access to housing in the Country & & & & & \\
\hline 3 & $\begin{array}{l}\text { There is Concern for Disrespect for adults and other marginalized } \\
\text { persons }\end{array}$ & & & & & \\
\hline 4 & Recreation and sports are available for post conflict healing & & & & & \\
\hline 5 & Citizens are empowered both socially and economically. & & & & & \\
\hline & Networks & & & & & \\
\hline 6 & People in the Country are supported for job training & & & & & \\
\hline
\end{tabular}




\begin{tabular}{|c|c|c|c|c|c|c|}
\hline \multirow[t]{2}{*}{7} & There is education for all & & & & & \\
\hline & $\begin{array}{l}\text { To what extent do you agree with the following statements? } \\
\text { Tick the scale }\end{array}$ & 1 & 2 & 3 & 4 & 5 \\
\hline 8 & $\begin{array}{l}\text { The institutions and government try to prevent crime in the } \\
\text { community }\end{array}$ & & & & & \\
\hline 9 & Counseling services are offered to victims of war & & & & & \\
\hline 10 & $\begin{array}{l}\text { There are institutions and programmes for youth and women } \\
\text { empowerment }\end{array}$ & & & & & \\
\hline \multirow[t]{2}{*}{11} & Concerns of certain groups heard more than other groups & & & & & \\
\hline & Cohesions & & & & & \\
\hline 12 & $\begin{array}{l}\text { People in the community talk freely with others (Freedom of } \\
\text { Speech). }\end{array}$ & & & & & \\
\hline 13 & I feel comfortable with people with different means $\backslash$ and class & & & & & \\
\hline 14 & $\begin{array}{l}\text { Social cohesions focus more specifically on social bonds through } \\
\text { Solidarity. }\end{array}$ & & & & & \\
\hline 15 & There are activities and programs to strengthen togetherness. & & & & & \\
\hline \multirow[t]{2}{*}{16} & $\begin{array}{l}\text { Leaders and institutions try to improve communication, for } \\
\text { coordinated group activities. }\end{array}$ & & & & & \\
\hline & Reciprocity & & & & & \\
\hline 17 & $\begin{array}{l}\text { The citizens in the Country have got that social dynamic in which } \\
\text { they are able to give, receive and return gifts }\end{array}$ & & & & & \\
\hline 18 & $\begin{array}{l}\text { There is a asocial commitment whereby a person receives a gift } \\
\text { and has a commitment to return what has been received freely }\end{array}$ & & & & & \\
\hline 19 & $\begin{array}{l}\text { There is provision of resources by an individuals and repayment of } \\
\text { resource of equivalent value }\end{array}$ & & & & & \\
\hline 20 & $\begin{array}{l}\text { High levels of social capital give rise to high level of reciprocal } \\
\text { relationship }\end{array}$ & & & & & \\
\hline 21 & There is more with cooperative and well-functioning societies & & & & & \\
\hline
\end{tabular}

Table 16: Institutional Response

\section{Section D: Conflict Management}

\begin{tabular}{|c|c|c|c|c|c|c|}
\hline & $\begin{array}{l}\text { To what extent do you agree/disagree with the following } \\
\text { statements? Tick the scale }\end{array}$ & 1 & 2 & 3 & 4 & 5 \\
\hline & The Need for Management & & & & & \\
\hline 1 & $\begin{array}{l}\text { The leaders try to identify their efficacy in managing natural resource } \\
\text { conflicts and disputes }\end{array}$ & & & & & \\
\hline 2 & There is sustainable management of natural resources in the region & & & & & \\
\hline 3 & $\begin{array}{l}\text { All the relevant stakeholders are engaged in the management of the } \\
\text { natural resources }\end{array}$ & & & & & \\
\hline 4 & $\begin{array}{l}\text { Leaders try to emotions manage the emotions of the citizens effectively } \\
\text { to avert full blown conflicts }\end{array}$ & & & & & \\
\hline \multirow[t]{2}{*}{5} & $\begin{array}{l}\text { People can meaningfully benefit from the exploitation of the natural } \\
\text { resources in an atmosphere of managed conflicts }\end{array}$ & & & & & \\
\hline & Judicial Mechanisms & & & & & \\
\hline 6 & $\begin{array}{l}\text { The national governments have established institutions especially the } \\
\text { judiciary organs of the government. }\end{array}$ & & & & & \\
\hline 7 & $\begin{array}{l}\text { It is the natural mandate of courts of law to entertain disputes in Juba } \\
\text { County }\end{array}$ & & & & & \\
\hline 8 & $\begin{array}{l}\text { Courts in South Sudan have encountered a number of problems related } \\
\text { to access to justice }\end{array}$ & & & & & \\
\hline 9 & The citizens have problems with paying court fees & & & & & \\
\hline \multirow[t]{2}{*}{10} & $\begin{array}{l}\text { The citizens have problems with the geographical location, complexity } \\
\text { of rules and procedure and the use of legalese in the courts of laws }\end{array}$ & & & & & \\
\hline & Negotiation & & & & & \\
\hline 11 & $\begin{array}{l}\text { Negotiation has been used in facilitating the effective management of } \\
\text { conflicts }\end{array}$ & & & & & \\
\hline
\end{tabular}




\begin{tabular}{|c|c|c|c|c|c|c|}
\hline 12 & $\begin{array}{l}\text { Negotiation has been involving parties meeting to identify and discuss } \\
\text { the issues at hand }\end{array}$ & & & & & \\
\hline 13 & $\begin{array}{l}\text { Leaders use efficient conflict management mechanisms in terms of } \\
\text { management of time, costs }\end{array}$ & & & & & \\
\hline \multirow[t]{2}{*}{14} & There has been negotiation between the County and other Counties & & & & & \\
\hline & $\begin{array}{l}\text { To what extent do you agree/disagree with the following } \\
\text { statements? Tick the scale }\end{array}$ & 1 & 2 & 3 & 4 & 5 \\
\hline \multirow[t]{2}{*}{15} & Negotiation helps in quickening the process of conflict management & & & & & \\
\hline & Mediation & & & & & \\
\hline 16 & $\begin{array}{l}\text { Mediation has been used in facilitating the effective management of } \\
\text { conflicts }\end{array}$ & & & & & \\
\hline 17 & $\begin{array}{l}\text { There has been a continuation of the negotiation process by other } \\
\text { means where instead of having a two-way negotiation }\end{array}$ & & & & & \\
\hline 18 & Leaders use efficient conflict management mechanisms with mediators & & & & & \\
\hline 19 & $\begin{array}{l}\text { Mediators have been successfully used to achieve the right of access to } \\
\text { justice for parties. }\end{array}$ & & & & & \\
\hline \multirow[t]{2}{*}{20} & Mediation helps in quickening the process of conflict management & & & & & \\
\hline & Arbitration & & & & & \\
\hline 21 & Arbitration has often been used as a dispute settlement mechanism & & & & & \\
\hline 22 & The Leaders sometimes appoint third parties in conflict management & & & & & \\
\hline 23 & $\begin{array}{l}\text { In some cases, parties in dispute agree to present their grievances to a } \\
\text { third party for resolution }\end{array}$ & & & & & \\
\hline 24 & The proceedings in commercial arbitration are always private & & & & & \\
\hline 25 & $\begin{array}{l}\text { Arbitration is essential in reconciliation processes of conflict } \\
\text { management }\end{array}$ & & & & & \\
\hline
\end{tabular}

Table 17: Conflict Management

\section{Leaders' Questionnaire}

I am a student at Cavendish University a Bachelor's Degree in International Relations and Diplomacy. As one of the requirements for the award of the above degree, I am required to carry out a research project. The research is to investigate the impact of Diplomatic relations and Institutional response on Conflict resolution with particular reference to Central Equatorial State in South Sudan. These questions are intended to facilitate this study. You have been randomly selected as a beneficiary of the above organization and you are kindly requested to spare some time and voluntarily respond to the following questions. All your responses will be treated confidentially.

Your input is highly appreciated.

\section{Please Tick Your Selected Option}

Section A: Bio data

1. Gender

Male $\square$ Female

2. Age Group

$21-30$ yrs.

$31-40$ yrs.

$41-50$ yrs.

$50+$ yrs

3. Marital status

Single $\square$ Married

Divorced $\square$ Others

4. Number of dependents

None $\square \quad \begin{array}{llll} & 1-3 \quad \square-6 \quad \square \quad \text { Above } 6 \square\end{array}$

5. Level of education

Secondary school $1 \square$ Certificate 3

Diplom $4 \square$ Degre $5 \square$ Masters 6

6. Number of years spent working with the state
$<1$ year
1-2 Yrs
2-4 Yrs
4-6 Yrs
Over 6 Yrs

Section B: Diplomatic Relations

Please check your feelings on governance by following the rating below and tick the appropriate choice: 5 - Strongly Agree (SA) 4 - Agree (A) 3 - Undecided (UD) 2 -Disagree (D) 1 - Strongly Disagree (SD) 


\begin{tabular}{|c|c|c|c|c|c|c|}
\hline & $\begin{array}{l}\text { Please indicate the rate at which you rank Diplomatic relations } \\
\text { Strategies in this company. Tick the scale }\end{array}$ & $\mathbf{1}$ & 2 & 3 & 4 & 5 \\
\hline & Economic Relations & & & & & \\
\hline 1 & There is increase in international trade in the Country & & & & & \\
\hline 2 & $\begin{array}{l}\text { There has been lowering of barriers to such trade and it leads to trade } \\
\text { wars and tariff }\end{array}$ & & & & & \\
\hline 3 & Economic relations results in improved international relations & & & & & \\
\hline 4 & $\begin{array}{l}\text { Economic relations affect global alliances, globalization and the economic } \\
\text { health of nations }\end{array}$ & & & & & \\
\hline \multirow[t]{2}{*}{5} & $\begin{array}{l}\text { There are recommends to develop, encourage, and maintain these } \\
\text { relations among diverse nations and cultures }\end{array}$ & & & & & \\
\hline & Cultural Relations & & & & & \\
\hline 6 & $\begin{array}{l}\text { There are interactions, both direct and indirect among two or more } \\
\text { cultures }\end{array}$ & & & & & \\
\hline 7 & $\begin{array}{l}\text { Cultural relations create pathways that can be leveraged to prevent or } \\
\text { resolve conflict }\end{array}$ & & & & & \\
\hline 8 & $\begin{array}{l}\text { The available cultural relations have created opportunities for engagement } \\
\text { with the goal of preventing and resolving conflicts }\end{array}$ & & & & & \\
\hline 9 & $\begin{array}{l}\text { The challenge of differences in language, understanding, perceptions and } \\
\text { practices between the military and the cultural communities have been } \\
\text { overcome }\end{array}$ & & & & & \\
\hline \multirow[t]{2}{*}{10} & $\begin{array}{l}\text { Culture is important in struggles that are increasingly global, especially in } \\
\text { terms of how to engage the effectiveness of adversarial engagement }\end{array}$ & & & & & \\
\hline & Environmental Relation & & & & & \\
\hline 11 & $\begin{array}{l}\text { There is management of the environmental relations between states and } \\
\text { between states and other actors }\end{array}$ & & & & & \\
\hline 12 & $\begin{array}{l}\text { Diplomacy is concerned with advising, shaping and implementing } \\
\text { environmental foreign policy }\end{array}$ & & & & & \\
\hline 13 & $\begin{array}{l}\text { States coordinate and secure particular or wider interests of the } \\
\text { environmental policies }\end{array}$ & & & & & \\
\hline 14 & There are good environmental relations in the County & & & & & \\
\hline \multirow[t]{2}{*}{15} & Environmental relations help in conflict management & & & & & \\
\hline & Political Relation & & & & & \\
\hline 16 & There are all forms of diplomatic interventions & & & & & \\
\hline 17 & There are mediations, international forums for conflict management & & & & & \\
\hline 18 & South Sudan has got good political relations with other countries & & & & & \\
\hline 19 & $\begin{array}{l}\text { There were requests for diplomatic intervention during the conflict } \\
\text { management processes }\end{array}$ & & & & & \\
\hline 20 & $\begin{array}{l}\text { The Country tried to recall the ambassadors and explicit offers to mediate } \\
\text { in the conflict management process }\end{array}$ & & & & & \\
\hline
\end{tabular}

Table 18: Diplomatic Relations

Section C: Institutional Response

\begin{tabular}{|c|c|c|c|c|c|c|}
\hline & $\begin{array}{c}\text { To what extent do you agree with the following statements? } \\
\text { Tick the scale }\end{array}$ & 1 & 2 & 3 & 4 & 5 \\
\hline \multicolumn{7}{|c|}{ Empowerment } \\
\hline 1 & $\begin{array}{l}\text { There is concern for Children skipping school as it could be } \\
\text { important for sustainable development }\end{array}$ & & & & & \\
\hline 2 & There is equal access to housing in the Country & & & & & \\
\hline 3 & $\begin{array}{l}\text { There is Concern for Disrespect for adults and other marginalized } \\
\text { persons }\end{array}$ & & & & & \\
\hline 4 & Recreation and sports are available for post conflict healing & & & & & \\
\hline 5 & Citizens are empowered both socially and economically. & & & & & \\
\hline \multicolumn{7}{|c|}{ Networks } \\
\hline 6 & People in the Country are supported for job training & & & & & \\
\hline 7 & There is education for all & & & & & \\
\hline 8 & $\begin{array}{l}\text { The institutions and government try to prevent crime in the } \\
\text { community }\end{array}$ & & & & & \\
\hline 9 & Counseling services are offered to victims of war & & & & & \\
\hline
\end{tabular}




\begin{tabular}{|c|c|c|c|c|c|c|}
\hline & $\begin{array}{c}\text { To what extent do you agree with the following statements? } \\
\text { Tick the scale }\end{array}$ & 1 & 2 & 3 & 4 & 5 \\
\hline 10 & $\begin{array}{l}\text { There are institutions and programmes for youth and women } \\
\text { empowerment }\end{array}$ & & & & & \\
\hline \multirow[t]{2}{*}{11} & Concerns of certain groups heard more than other groups & & & & & \\
\hline & Cohesions & & & & & \\
\hline 12 & $\begin{array}{l}\text { People in the community talk freely with others (Freedom of } \\
\text { Speech). }\end{array}$ & & & & & \\
\hline 13 & I feel comfortable with people with different means \and class & & & & & \\
\hline 14 & $\begin{array}{l}\text { Social cohesions focus more specifically on social bonds through } \\
\text { Solidarity. }\end{array}$ & & & & & \\
\hline 15 & There are activities and programs to strengthen togetherness. & & & & & \\
\hline \multirow[t]{2}{*}{16} & $\begin{array}{c}\text { Leaders and institutions try to improve communication, for } \\
\text { coordinated group activities. }\end{array}$ & & & & & \\
\hline & Reciprocity & & & & & \\
\hline 17 & $\begin{array}{l}\text { The citizens in the Country have got that social dynamic in which } \\
\text { they are able to give, receive and return gifts }\end{array}$ & & & & & \\
\hline 18 & $\begin{array}{l}\text { There is a asocial commitment whereby a person receives a gift } \\
\text { and has a commitment to return what has been received freely }\end{array}$ & & & & & \\
\hline 19 & $\begin{array}{c}\text { There is provision of resources by an individuals and repayment of } \\
\text { resource of equivalent value }\end{array}$ & & & & & \\
\hline 20 & $\begin{array}{l}\text { High levels of social capital give rise to high level of reciprocal } \\
\text { relationship }\end{array}$ & & & & & \\
\hline 21 & There is more with cooperative and well-functioning societies & & & & & \\
\hline
\end{tabular}

Table 19: Institutional Response

Section E: Conflict Management

\begin{tabular}{|c|c|c|c|c|c|c|}
\hline & $\begin{array}{l}\text { To what extent do you agree/disagree with the following statements? Tick the } \\
\text { scale }\end{array}$ & 1 & 2 & 3 & 4 & 5 \\
\hline & The Need for Management & & & & & \\
\hline 1 & $\begin{array}{c}\text { As leaders, we try to identify their efficacy in managing natural resource } \\
\text { conflicts and disputes }\end{array}$ & & & & & \\
\hline 2 & There is sustainable management of natural resources in the region & & & & & \\
\hline 3 & $\begin{array}{c}\text { All the relevant stakeholders are engaged in the management of the natural } \\
\text { resources }\end{array}$ & & & & & \\
\hline 4 & $\begin{array}{c}\text { We try to emotions manage the emotions of the citizens effectively to avert full } \\
\text { blown conflicts }\end{array}$ & & & & & \\
\hline \multirow[t]{2}{*}{5} & $\begin{array}{l}\text { People can meaningfully benefit from the exploitation of the natural resources } \\
\text { in an atmosphere of managed conflicts }\end{array}$ & & & & & \\
\hline & Judicial Mechanisms & & & & & \\
\hline 6 & $\begin{array}{c}\text { The national governments have established institutions especially the judiciary } \\
\text { organs of the government. }\end{array}$ & & & & & \\
\hline 7 & It is the natural mandate of courts of law to entertain disputes in Juba County & & & & & \\
\hline 8 & $\begin{array}{l}\text { Courts in South Sudan have encountered a number of problems related to } \\
\text { access to justice }\end{array}$ & & & & & \\
\hline 9 & The citizens have problems with paying court fees & & & & & \\
\hline \multirow[t]{2}{*}{10} & $\begin{array}{l}\text { The citizens have problems with the geographical location, complexity of rules } \\
\text { and procedure and the use of legalese in the courts of laws }\end{array}$ & & & & & \\
\hline & Negotiation & & & & & \\
\hline 11 & Negotiation has been used in facilitating the effective management of conflicts & & & & & \\
\hline 12 & $\begin{array}{l}\text { Negotiation has been involving parties meeting to identify and discuss the } \\
\text { issues at hand }\end{array}$ & & & & & \\
\hline 13 & $\begin{array}{l}\text { Leaders use efficient conflict management mechanisms in terms of } \\
\text { management of time, costs }\end{array}$ & & & & & \\
\hline 14 & There has been negotiation between the County and other Counties & & & & & \\
\hline 15 & Negotiation helps in quickening the process of conflict management & & & & & \\
\hline & Mediation & & & & & \\
\hline
\end{tabular}




\begin{tabular}{|c|c|c|c|c|c|c|}
\hline \multirow{3}{*}{16} & Mediation has been used in facilitating the effective management of conflicts & & & & & \\
\hline & $\begin{array}{c}\text { There has been a continuation of the negotiation process by other means } \\
\text { where instead of having a two-way negotiation }\end{array}$ & & & & & \\
\hline & $\begin{array}{c}\text { To what extent do you agree/disagree with the following statements? } \\
\text { Tick the scale }\end{array}$ & 1 & 2 & 3 & 4 & 5 \\
\hline 18 & Leaders use efficient conflict management mechanisms with mediators & & & & & \\
\hline 19 & $\begin{array}{l}\text { We have been successfully used to achieve the right of access to justice for } \\
\text { parties. }\end{array}$ & & & & & \\
\hline 20 & Mediation helps in quickening the process of conflict management & & & & & \\
\hline & Arbitration & & & & & \\
\hline 21 & Arbitration has often been used as a dispute settlement mechanism & & & & & \\
\hline 22 & We sometimes appoint third parties in conflict management & & & & & \\
\hline 23 & $\begin{array}{l}\text { In some cases, parties in dispute agree to present their grievances to a third } \\
\text { party for resolution }\end{array}$ & & & & & \\
\hline 24 & The proceedings in commercial arbitration are always private & & & & & \\
\hline 25 & Arbitration is essential in reconciliation processes of conflict management & & & & & \\
\hline
\end{tabular}

Table 20: Conflict Management

\begin{tabular}{|c|c|c|c|c|}
\hline No. & ITEM & Quantity & Cost/Unit (SSP) & $\begin{array}{c}\text { Total cost } \\
\text { (SSP) }\end{array}$ \\
\hline 1. & Stationery & 1 (ream) & 50 & 50 \\
\hline 2. & Printing \& Binding & - & 70 & 70 \\
\hline 3. & Communication & - & 1500 & 600 \\
\hline 4. & Transport & - & 500 & 500 \\
\hline 5. & Lunch & 5 days & 50 & 250 \\
\hline 6. & Miscellaneous & - & 300 & 300 \\
\hline 7 & Data analysis & & & 400 \\
\hline Total & & & & 2170 \\
\hline
\end{tabular}

Table 21: Budget Estimates

\begin{tabular}{|c|c|c|}
\hline Date & Activity & Person Responsible \\
\hline March 2012 & $\begin{array}{c}\text { Proposal writing. Developing research } \\
\text { instruments and submission }\end{array}$ & Researcher and Supervisor \\
\hline April 2012 & Proposal review and Pilot Testing of tools & Researcher and Supervisor \\
\hline May 2012 & Data collection & Researcher \\
\hline June 2012 & Data processing and Analysis & Researcher \\
\hline July 2012 & Report writing & Researcher and Supervisor \\
\hline August 2012 & Final report submission & Researcher and Supervisor \\
\hline
\end{tabular}

Table 22: Work Plan 